\title{
Suspended sediment yield mapping of Northern Eurasia
}

\author{
K.A. MALTSEV, O.P. YERMOLAEV \& V.V. MOZZHERIN \\ Kazan Federal University, Department of the Landscape Ecology, Institute of Ecology and Geography, 18 Kremlevskay \\ St, Kazan, Russia, 420008 Kazan, Russia \\ mlcvkirill@rambler.ru
}

\begin{abstract}
The mapping of river sediment yields at continental or global scale involves a number of technical difficulties that have largely been ignored. The maps need to show the large zonal peculiarities of river sediment yields, as well as the level (smoothed) local anomalies. This study was carried out to create a map of river sediment yields for Northern Eurasia (within the boundaries of the former Soviet Union, $22 \times 10^{6} \mathrm{~km}^{2}$ ) at a scale of 1:1500 000. The data for preparing the map were taken from the long-term observations recorded at more than 1000 hydrological stations. The data have mostly been collected during the 20th century by applying a single method. The creation of this map from the study of river sediment yield is a major step towards enhancing international research on understanding the mechanical denudation of land due mainly to erosion.
\end{abstract}

Key words suspended sediment yield; GIS; thematic map; watershed boundaries; Northern Eurasia

\section{INTRODUCTION}

The mapping of river suspended sediment yield is the most significant challenge for the experts working in the fields of hydrology and geomorphology. This challenge can be attributed mainly to the sparse network of hydrological stations that systematically observe sediment yield. Therefore, the interpolation of sediment yield records for unexplored river basins is required. Sediment yield and the catchment area have a complex relationship, which requires a careful approach in selecting the basins for creating the sediment yield maps. Another challenge in the preparation of a new map is the large number of sediment yield indicators. Each of these indicators can potentially be used for sediment yield mapping. Furthermore, the discrete nature of sediment yield is necessary for accurate mapping. The substantial variation within the borders of neighboring catchments limits the number of methods appropriate for representing this phenomenon cartographically.

Sediment yield mapping attempts, in which river basins serve as territorial units, were performed for the eastern part of the Russian Plain. For example, the following aspects of the study area were investigated: examining the calculated values of the suspended sediment yield in the basins of small rivers with a mathematical-statistical model of the sediment yield, building the map on the spread of the sediment yield, and analysing the spatial trends of the suspended sediment yield (SSY) in the basins of small rivers. The areas of study were within the forests, forest-steppes, and northern part of the steppe landscape of the Russian Plain, which spans more than $130 \times 10^{3} \mathrm{~km}^{2}$. The calculated values of the sediment yield module for each of the 3331 basins of the examined territory were calculated by Yermolaev (2013).

The SSY mapping of the Volga River basin was performed with the use of GIS technologies. The Volga River flows $1000 \mathrm{~km}$ from east to west and $1500 \mathrm{~km}$ from north to south, covering a total area of $757000 \mathrm{~km}^{2}$, and including 110 tributary river basins. SSY mapping involved $53 \%$ of the total area of the Volga River basin. As a result, the maps on the suspended sediment yield for the basin included areas of taiga, mixed and broadleaf forests, forest-steppes, steppes and semi-deserts (Maltsevet al. 2012; Yermolaev et al. 2012; Yermolaev, 2014).

\section{METHODS}

Long-term records of riverine sediments (1955-1975 years) served as the source of data to map suspended sediment yield at a scale of 1:1 500000 in the territory of Northern Eurasia (within the former Soviet Union, this territory extends over $22.402 \times 10^{6} \mathrm{~km}^{2}$ ). The data were collected from more than 1000 stations of the national hydrological monitoring service. These data were obtained during the 20th century using a single method. The riverbed sediment yield was not considered in this study because of the exceptive approximation of its natural definition. The observations 
obtained from the data mainly covered the European part of the former USSR $\left(3.96 \times 10^{6} \mathrm{~km}^{2}\right)$, which accounts for almost $60 \%$ of the hydrological stations. The average long-term values of the sediment yield $r$ were used when the original data set was processed. These values were expressed in $\mathrm{t} \mathrm{km}^{2}$ year ${ }^{-1}$ :

$$
r=(R / S) \cdot 31.5 \cdot 10^{3}
$$

where $R$ is the sediment discharge in $\mathrm{kg} / \mathrm{s}$, and $S$ is the river catchment area in $\mathrm{km}^{2}$.

This indicator allows the comparison of the hydrological characteristics of different basin areas on a common basis. The value of $r$ was calculated with an accuracy of up to two decimal places. This was considered adequate because of the relatively low accuracy (error about $8 \%-$ $10 \%$ ) in determining suspended sediment (Dedkov \& Mozzherin, 1984).

A number of hydrological stations operated from 1940 to 1975 in the former USSR. For at least 10 years, these stations were used to process observations on suspended sediment yield. We used mostly data for the period from 1955 to 1975, which were published in state water cadastre of the former USSR. The 10 year period is adequate for obtaining statistically reliable values of suspended sediment yield. The yield standard (value of the suspended sediment yield) show a significant level of stability over the 10 year period. Consequently, the map is still useful although it was developed on the basis of 50-year-old data. In our opinion, the map reflects the fundamental laws of spatial distribution concerning suspended sediment yield in this large area of the planet with its varied types of landscape conditions.

The boundaries of the catchment basin were determined for each hydrological station, and the data from these stations were used in the mapping study. The entire set of geographic and attribute data was edited in a geographic information database.

The techniques applied for the automated identification of drainage basin boundaries affect the quality of mapping. They (drainage basins) were used as operational-territorial units, and the information on water and sediment yield is connected with mapped drainage basins like. At present, identifying the drainage basin boundaries for large areas by GIS technology is productive in automatic mode in which the digital terrain models and vector maps of the hydrographic network are used as initial data. Some of the software programs (commercial and free ones), which allow the delineation of catchment area boundaries in automatic mode, are ArcGIS, GRASS, QGIS, TAS, SAGA, ANUDEM, and PCRASTER. Note that the boundaries automatically created with different software programs having the same terrain model are fundamentally not different (Zamfir \& Simulescu, 2011). The quality and details of the digital terrain model (DTM) can significantly affect the quality of the selected (drawing) basin boundaries within a certain area. The most important factors are the peculiarities in the geomorphologic structure of the area.

The following set of initial data was utilized to draw the catchment basin boundaries throughout the area selected for the study: the global digital terrain model GTOPO30, the vector map of the hydrographic network, and the map on the location of hydrological stations. The GTOPO30 model possesses some disadvantages. It contains artifacts in the form of closed local depressions which are false areas of water runoff interception and sediments when a terrain model is used. Consequently, the catchment area and shape are significantly distorted. It is necessary to prepare a special DTM when an automated technology is used for identifying the drainage basin boundaries (Maltsev et al., 2012).

This study employs two different approaches in DTM preparation. The first approach is the total removal of artificial and actual closed depressions that exist in DTM GTOPO30, including their areas in the common catchment area. The total removal of depressions is justified in the case of more depressions in the terrain model, which are artifacts, compared to the count of real depressions (Lindsay, 2005). This approach was employed for the European part of Russia, which satisfied the condition.

The second approach was used in the Western Siberian territory with a number of real closed depressions. This approach involved the selective removal of closed depressions that existed in DTM GTOPO30; additional information on the location of water bodies in a vector map were used (Maltsev \& Yermolaev, 2014). 
The results of the study were used for developing a GIS database of the catchment basin boundaries. This database was based on the locations of gauging points (Yermolaev et al., 2012) and included data on the areas, water runoff and suspended sediments of 1579 rivers. The mapping of the suspended sediments was conducted on the basis of the available database by applying different methodological approaches. The first approach was implemented for mapping the Volga river basin. The catchments of the gauging station and the suspended sediment value were used as the mapping units (Maltsev et al., 2012). However, this approach was time consuming and almost impossible to automate.

Another approach for river sediment yield mapping was implemented in Northern Eurasia (in the former USSR). Physiographic (landscape) areas were used as the territorial units for mapping. These areas were presented on a thematic map at a scale of 1:15000000 in the physical and geographical atlas of the world issued in 1964 and edited in 2007 (National Atlas, 2007). The entire Northern Eurasia was divided into natural zones (from arctic deserts to semi-deserts or temperate zones). Each landscape zone was subdivided into sectors according to climate and orographic conditions. The total number of allocated landscapes was more than 200. Using landscape zones to map the suspended sediment yield was justified by the zonal variation in the flow of suspended sediment yield. The average value of suspended sediments was calculated in natural areas and sectors. If at least three-quarters of a basin's area belonged to one natural zone, the amount of suspended sediment yield calculated for this basin was used to estimate the average sediment yield within a specific landscape area. Otherwise, the basin was excluded from calculations.

Ideally, the mapping data for the mean values of sediment yield throughout river basin areas within the range $10-100 \times 10^{3} \mathrm{~km}^{2}$ range should be used. These data are optimal for the zonal peculiarities of sediment yield. The sensitivity of small catchments to local zonal factors of sediment yield formation, primarily to orography and mountain rock composition that are not typical of this region, can be considered proven (Shamov, 1959; Karaush, 1977; Dedkov \& Mozzherin, 1984; Mozzherin, 1994; Bobrovitskaya, 1995). By contrast, large catchment areas located within a few landscape zones smooth zonal features, and the volume of sediment yield for these rivers is not typical of any separate landscape zone. However, if such conditions are to be considered for mapping, the analysis will include 100 basins from 1579 samples. The lower limits of the basin area were completely removed for mapping, and the upper limits were expanded to $200 \times 10^{3} \mathrm{~km}^{2}$. Therefore, the sample volume involved in determining the suspended sediment yield was 1500 units.

\section{RESULTS AND DISCUSSION}

Using the records on riverine suspended sediment yield (1955-1975), an electronic vector map of the suspended sediment yield was prepared, using the preceding instructional techniques, for the Northern Eurasia for the first time (Fig. 1). All the landscaped areas (zones) and sectors were divided into five groups: I - areas with very high $r$ values $\left(250\right.$ or more $\mathrm{t} \mathrm{km}^{-2}$ year $\left.{ }^{-1}\right)$, II - areas with high $r$ values $\left(100-250 \mathrm{t} \mathrm{km}^{-2}\right.$ year $\left.^{-1}\right)$, III - zones with moderate $r$ values $\left(50-100 \mathrm{t} \mathrm{km}^{-2} \cdot\right.$ year $\left.^{1}\right)$, IV zones with low $r$ values (10-50 t km${ }^{-2}$ year $^{-1}$ ), and $\mathrm{V}$ - zones with very low $r$ values (less than $10 \mathrm{t}$ $\mathrm{km}^{-2}$ year-1 $)$. The first two groups were presented by axial, mostly elevated zones of young epigeosynclinal mountains (for example, Caucasian mountains, Pamir) and ancient perigeosynclinal mountains (e.g. Tien Shan and others). The intensity of erosion in the basins of rivers from this group was entirely controlled by orographic conditions, particularly by the absolute altitude and slope steepness. The potential relief and kinetic energies of water flow in these young epigeosynclinal mountains are so high that these zones are the areas with the most severe erosion (or denudation) which generate the largest river sediment yield in the world. The third group is composed of moderately high mountains (Carpathians) and is known for its significant suspended sediment yield. However, this yield is lower than those of the preceding categories.

An analysis of the new map on the river suspended sediment yield from the Northern Eurasia shows the following conclusions. Suspended sediment yield is poorly explored over large areas of The Northern Eurasia, including the Russian North, Asian part of Russia, Kazakhstan, and Central 

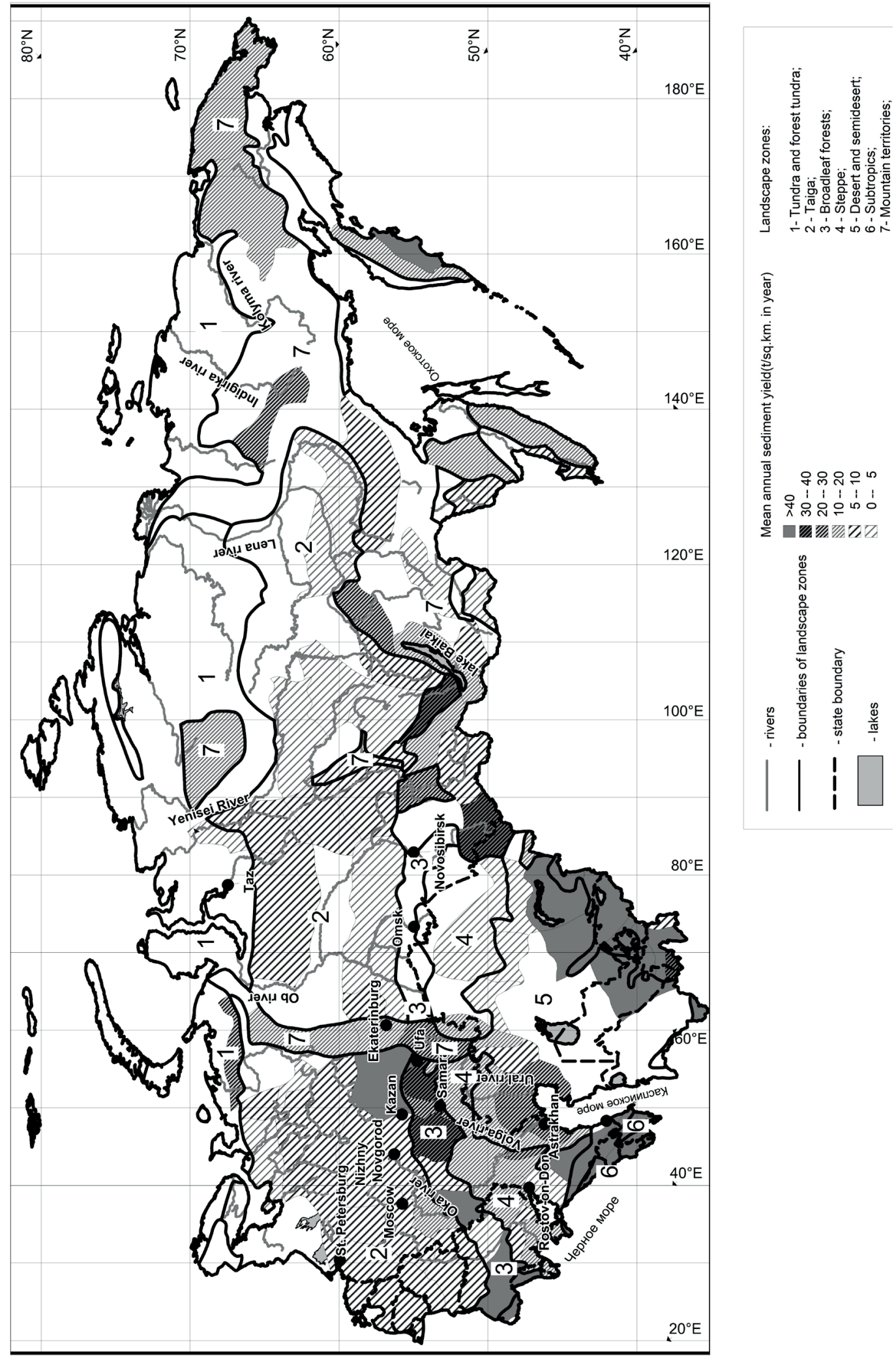

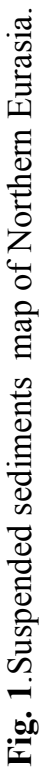


Asia. These areas are left as white spots on the map because of the absence of reliable mathematical and statistical models that allow the extrapolation of sediment yield value on unexplored rivers (Mozzherin \& Mozzherin, 2011).

The main factors that affect the zonal and sectoral distribution of erosion intensity and sediment yield on the plains and low hills are the degree of economic development and water flow. The latter is an integral representation of climatic conditions. The zonal effect of anthropogenic factors is attributed to differences in the extent of human exploration in geographical zones as a result of natural conditions (climate, soil, vegetation). An increase in exploration level increases erosion and the suspended sediment yield. Azonal factors, such as topography and rock composition, do not significantly affect the zonal distribution of suspended sediment yield on lowland rivers.

The regions with the highest suspended sediment yield on the plains and low hills of Northern Eurasia are confined to zones with intense and prolonged agricultural development. These regions are the southern half of the East European Plain and the northern foothills of the Caucasus. The Southern Siberia Mountains have almost the same values of suspended sediment yield. Low $r$ values are typical of middle mountains of the Far East (Kamchatka, Primorye), which are dominated by dense taiga woods. The lowest values of $r$ are observed in poorly developed taiga landscapes in the northern part of the East European Plain, which is mostly a part of Siberia. In this area, the zone shows a tendency to decrease suspended sediments after a reduction in water flow from the ocean waters to inland. For example, in the Volga River basin, runoff of suspended sediment measured at the main tributaries and the main channel of the river does not exceed 23 $\mathrm{t} \mathrm{km}^{-2}$ year $^{-1}$ (Table 1). The exception is the Mesha basin where suspended sediment runoff reaches $130 \mathrm{t} \mathrm{km}^{-2}$ year $^{-1}$ (Fig. 2).

Table 1 Suspended sediment yield from the some major tributary river basins in the Volga River basin.

\begin{tabular}{lllrr}
\hline № & Rivers & HS & $\begin{array}{l}\text { SSY } \\
\left(\mathrm{t} \mathrm{km}^{-2} \text { year }^{-1}\right)\end{array}$ & \multicolumn{1}{c}{$\begin{array}{l}\text { CA } \\
\left(\mathrm{km}^{2}\right)\end{array}$} \\
\hline 1 & Volga & Rzhev & 3.3 & 12200 \\
2 & Mologa & Ustyuzhna & 1.7 & 19100 \\
3 & Kostroma & Bui & 7 & 8870 \\
4 & Volga & Yaroslavl & 4.2 & 154000 \\
5 & Unzha & Manturovo & 11 & 16200 \\
6 & Vetluga & Dubniki & 6.2 & 27700 \\
7 & Oka & Novinka & 9.1 & 245000 \\
8 & Bolshaya Kokshaga & Grishkino & 8.2 & 5750 \\
9 & Volga & Vyazovie & 12 & 629000 \\
10 & Mesha & Obukhovka & 130 & 3640 \\
11 & Vyatka & Vyatskie Polyana & 23 & 124000 \\
12 & Kama & Naberezhnye Chelny & 17 & 370000 \\
13 & Belaya & Birsk & 23 & 121000 \\
14 & Chusovaya & Nizhnie Shalygy & 19 & 23300 \\
15 & Zay & Zainsk & 20 & 2920 \\
16 & Bolshoy Cheremshan & Melekess & 16 & 11500 \\
17 & Bolshaya Kinel & Timashevo & 13 & 12000 \\
18 & Bolshoy Irgiz & Berezovo & 4.4 & 19800 \\
19 & Yeruslan & Peschanka & 8.3 & 4200 \\
20 & Volga & Verhnelebyazhe & 6.7 & 1360000 \\
\hline
\end{tabular}

HS, hydrological stations in populated localities; SSY, suspended sediment yield; CA, the catchment area. 


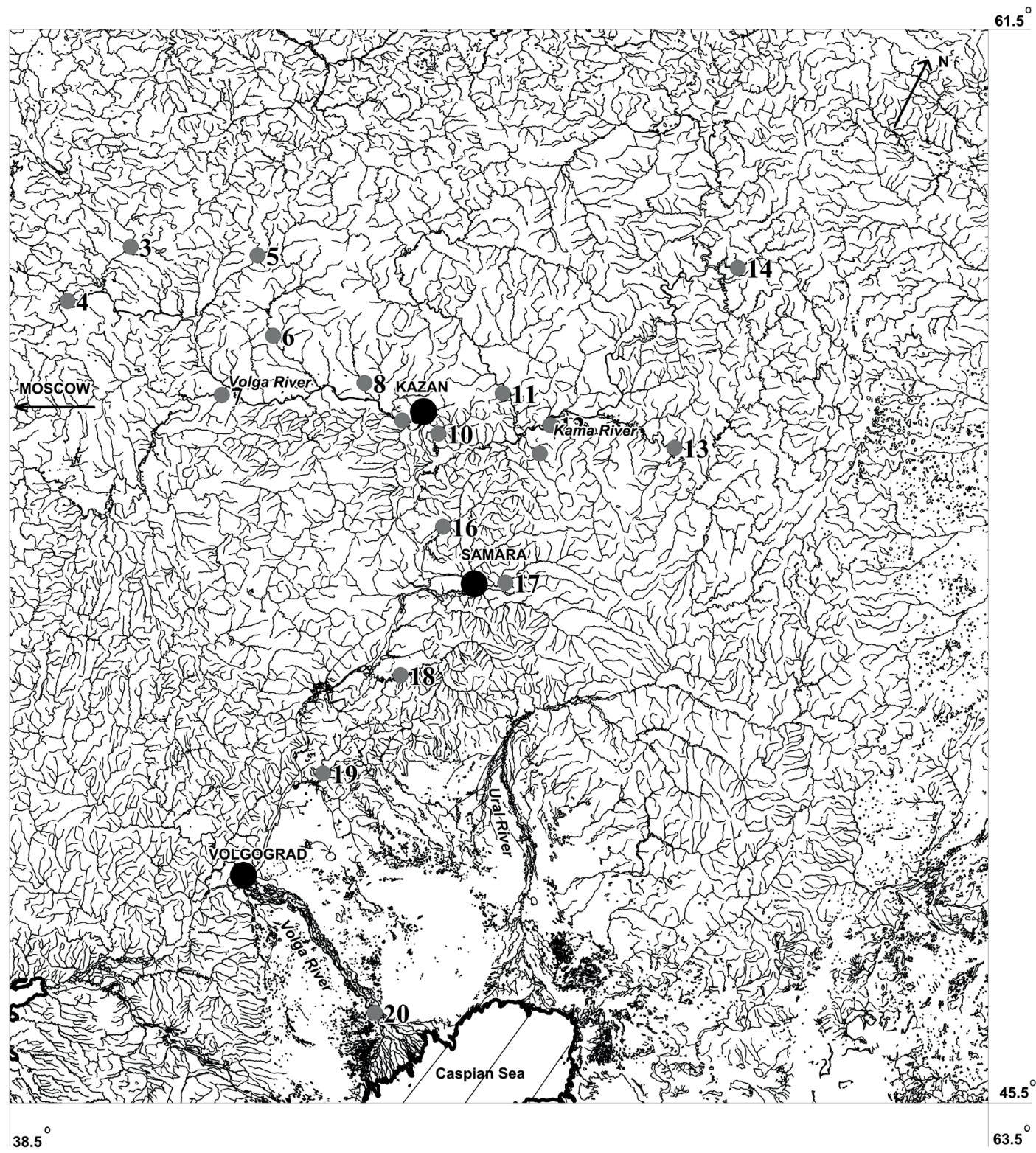

$0 \quad 500 \quad 1000$ (км)

- 1 - hydrological stations where the suspended sediments yield is observed and their numbers

rivers

- towns

Fig. 2 Location of some hydrological measurement stations in the Volga River basin.

\section{CONCLUSION}

A key problem for further improving the mapping of suspended sediment yield for the rivers of the Northern Eurasia is the calculation of probable $r$ values for those areas that do not have hydrological observations. In practice, this problem can be resolved on a regional level with the use of mathematical and statistical models of erosion and sediment yield. 


\section{REFERENCES}

Bobrovitskaya, N.N. (1995) Water erosion on slopes and river sediment yield. Full doctor thesis, St. Petersburg: GGI (in Russian).

Burrough, P.A. \& McDonnell R.A. (1998) Principles of Geographical Information Systems: Spatial Information Systems and Geostatistics. Oxford University Press.

Dedkov, A. P. \&Mozzherin, V. I. (1984) Erosion and Suspended Sediment on the Earth. Kazan: Publishing house KSU (in Russian).

Gerasimov, I.P. ed. (1964) Physical and Geographic World Atlas. Moscow: GUGK (in Russian).

Hengl, T. \& Hannes, I. R. eds. (2007) Developments in Soil Science - Volume 33: Geomorphometry: Concepts, Software, Applications. Luxembourg: Office for Official Publications of the European Communities.

Karaush, A.V. ed. (1977) Sediment Yield, Its Study and Geographical Distribution. Leningrad: Gidrometeoizdat. (in Russian).

Levitin, I.V. ed. (2007) The National Atlas of Russia. V. 2. Moscow: PKO "Cartography". (in Russian).

Lindsay, J.B., (2005) The terrain analysis system: a tool for hydrogeomorphic applications. Hydrological Processes 19(5), $1123-1130$.

Maltsev, K.A. \& Yermolaev O.P. (2014) Using DEMs for automatic plotting of catchments. Geomorphologiya 1, 45-53 (in Russian).

Maltsev, K.A., Yermolaev, O.P. \& Mozzerin, V.V. (2012) Mapping and spatial analysis of suspended sediment yields from the Russian Plain. In: Erosion and Sediment Yields in the Changing Environment (ed. by A.L. Collins et al.) IAHS Publ. 356, 251-258. IAHS Press, Wallingford, UK.

Mozzherin, V.I. (1994) Geomorphological analysis of solid river flow for humid plains of temperate zone. Full doctor thesis St. Petersburg: GGI (in Russian).

Mozzherin, V.I. \& Mozzherin, V.V. (2011) Global suspended sediment yield: its geomorphological and geo-ecological interpretation. Geomorphologiya 1, 13-24.

Shamov, G.I. (1959) River Sediments. Liningrad: Gidrometeoizdat (in Russian).

Wilson, J.P. \& Gallant, J.C. eds. (2000) Terrain Analysis: Principles and Applications. New York: John Wiley and Sons.

Yermolaev, O.P. (2013) Assessment of the suspended sediment yield in the rivers' basins of the Russian Plain. World Applied Sciences Journal 27 (5), 626-631.

Yermolaev, O. P. (2014) Erosion Processes of the Forest and Forest-Steppe Zones in the Eastern Part of the Russian Plain. World Applied Sciences Journal 29 (3), 453-459.

Yermolaev, O.P. \& Semenov, F.V. (2014) The use of Digital Elevation Models for morphometric analysis of tectonic structures and search placers alluvial genesis. Geography and Natural Resources 1, 142-147.

Yermolaev, O.P., et al. (2012) Global geoinformation system "Suspended sediment yield in the river basins of the Earth". Geomorphologiya 2, 50-57 (in Russian).

Zamfir, A. \& Simulescu, D. (2011) Automatic delineation of a watershed using a DEM. Case study - the Oulteţ watershed. ANALELE Universităţii,, Ştefancel Mare, Suceava, Seria Geografie, 83-92. 